\title{
Tác dụng chống viêm cấp và mạn của hợp chất ent-7 $\beta$ - hydroxy-15-oxokaur-16-en-18-yl acetate từ khổ sâm cho lá
}

\author{
Nguyễn Văn Thoan ${ }^{1}$, Trần Thị Thu Hiền ${ }^{2}$, \\ Nguyễn Duy Thuần ${ }^{2}$, Phương Thiện Thương ${ }^{3, *}$ \\ ${ }^{I}$ Viện Nghiên cứu Phát triển Y dược Phuơng Đông, Công ty Cổ phần Dược phẩm Quốc gia, \\ 119 Nguyễn Ngọc Nại, Thanh Xuân, Hà Nộ \\ ${ }^{2} H o ̣ c$ viện Y Dược học Cổ truyền Việt Nam, số 2 Trần Phú, Hà Đông, Hà Nội \\ ${ }^{3}$ Viện Duoọc liệu, số $3 B$ Quang Trung, Hoàn Kiếm, Hà Nội
}

\section{Tóm tắt}

Nghiên cứu này được thực hiện nhằm đánh giá tác dụng chống viêm cấp và mạn của hợp chất ent-7 $\beta$ hydroxy-15-oxokaur-16-en-18-yl acetate (CT1) phân lập từ cây khổ sâm cho lá bằng các mô hình thực nghiệm. Ở mô hình gây phù bàn chân chuột cống bằng carrageenan, chất CT1 (liều uống $50 \mathrm{mg} / \mathrm{kg} / \mathrm{ngày}$ ) có tác dụng làm giảm phù bàn chân chuột $24,73 \%(\mathrm{p}<0,05)$ tại thời điểm 5 giờ sau khi gây viêm. Trên mô hình đánh giá tác dụng làm giảm khối u mạn gây bằng bông trên chuột cống trắng, chất CT1 (liều uống $25 \mathrm{mg} / \mathrm{kg} /$ ngày) có tác dụng làm giảm khối lượng u hạt $24,67 \%(\mathrm{p}<0,05)$. Các kết quả thu được chứng minh rằng chất $\mathrm{CT} 1$ có tác dụng chống viêm và gợi ý rằng đây có thể là hoạt chất của dược liệu khổ sâm cho lá khi sử dụng làm thuốc chống viêm, chống dị ứng trong y học dân gian.

Nhận ngày 26 tháng 9 năm 2015, Chỉnh sửa ngày 21 tháng 11 năm 2015, Chấp nhận đăng ngày 05 tháng 12 năm 2016 Tù khóa: Khổ sâm cho lá, chống viêm, ent-7ß-hydroxy-15-oxokaur-16-en-18-yl acetate.

\section{1. Đặt vấn đề}

Trong số các cây thuốc được nhân dân các dân tộc nước ta sử dụng, có rất nhiều loài còn chưa được nghiên cứu đầy đủ về thực vật học, thành phần hóa học và tác dụng sinh học. Đặc biệt có nhiều loài còn là loài đặc hữu của Việt Nam là đối tượng rất tiềm năng cho nghiên cứu và phát triển thuốc. Trong số này, cây thuốc khổ sâm cho lá (Croton tonkinensis Gagnep.) được nhân dân các nơi sử dụng làm thuốc chống viêm loét dạ dày, mẩn ngứa, ghẻ lở [1-4]. Qua quá trình thăm dò bước đầu, chúng tôi phát hiện thấy cây thuốc này còn có tác dụng ức chế

\footnotetext{
* Tác giả liên hệ. ĐT: 84-4-39363378

Email: phuongthienthuong@yahoo.com
}

sự sưng viêm, do đó có tác dụng giảm đau khi thử trên các mô hình in vitro. Đặc biệt, thành phần hóa học chính của khổ sâm cho lá là một diterpenoid nhóm ent-kauran là ent-7 $\beta$ hydroxy-15-oxokaur-16-en-18-yl acetate (ký hiệu là CT1) cũng cho tác dụng chống viêm rất mạnh trên mô hình thử in vitro [5-8], gợi ý rằng chất này chính là hoạt chất mang lại tác dụng chống viêm của dược liệu này. Tuy nhiên đến nay chưa có nghiên cứu nào đánh giá về các tác dụng chống viêm, giảm đau của hợp chất chính phân lập được trên mô hình in vivo. Do đó, chúng tôi đặt vấn đề đánh giá tác dụng chống viêm cấp và mạn tính của diterpenoid CT1 từ cây khổ sâm cho lá (Croton tonkinensis Gagnep.)" bằng mô hình gây viêm trên chuột cống. 


\section{Nguyên vật liệu và phương pháp nghiên cứu}

\subsection{Nguyên vật liệu}

Chất CT1 (ent-7ß-hydroxy-15-oxo kaur-16en-18-yl acetat) được phân lập và xác định cấu trúc như đã mô tả trong nghiên cứu trước đây phân lập được có độ tinh khiết cao (nhiệt độ nóng chảy ổn định, độ tinh khiết $96 \%$ tính theo phần trăm diện tích pic trên máy HPLC, được thể hiện trên phổ ${ }^{1} \mathrm{H}$ và ${ }^{13} \mathrm{C}-\mathrm{NMR}$ ) [9]. Các hóa chất dùng cho thử tác dụng sinh học gồm: carrageenan (Sigma Aldrich), indomethacin (chuẩn phân tích), prednisolon (Jenapharm), nước muối sinh lý (B/Braun), dung dịch chống thấm đo viêm (Ugo Basile, Italia), amian tiệt trùng các hóa chất dùng để pha dung dịch đệm đều đạt chuẩn cho thử tác dụng sinh học.

\section{2. Động vật}

Chuột nhắt trắng chủng Swiss, giống đực, khỏe mạnh, nặng 18-22 g, được cung cấp bởi Viện Vệ sinh dịch tễ Trung ương dùng để đánh giá độc tính cấp. Chuột cống trắng chủng Wista, giống đực, khoảng 8 tuần tuổi, cân nặng 140-180 g, do Học viện Quân y cung cấp. Động vật được nuôi ổn định trong điều kiện phòng thí nghiệm 5 ngày trước khi thực hiện nghiên cứu. Thức ăn do Viện Vệ sinh dịch tễ TW cung cấp, uống nước tự do.

\subsection{Trang thiết bị dùng cho nghiên cưu}

Máy đo pH, Máy sinh hóa TC 84 Plus (Teco Diagnostics), Máy đo độ phù chân chuột Plethysmometer (Ugo Basile), Máy đo đau mâm nóng (Ugo Basile); Cân kỹ thuật (Precisa), cân phân tích (Shimadzu). Các dụng cụ thí nghiệm sinh học: pipet, micropipette, ống nghiệm các loại.

\section{4. Đánh giá độc tính cấp của chất CT1}

Độc tính cấp của dược liệu và của chất phân lập được thư trên chuột theo phuoong pháp do Bộ Y tế ban hành [10]. Độc tính cấp của chất phân lập được biểu diễn bởi giá trị $L D_{50}$, được hiểu là giá trị làm chết $50 \%$ số chuột thí nghiệm. Giá trị $L D_{50}$ đuoơc tính theo phuoong pháp Behrens-Karber [10].

\section{5. Đánh giá tác dụng chống viêm cấp}

Tác dụng chống viêm cấp của chất phân lập được thử bằng mô hình gây phù bằng carrageenan theo Winter trên chuột cống trắng $[10,11]$. Chuột thí nghiệm được chia ngẫu nhiên thành 4 lô, mỗi lô 10-12 con, gồm có lô chứng (lô 1): được cho uống dung môi (nước muối sinh lý); lô đối chiếu (lô 2): uống thuốc đối chiếu (indomethacine); và 02 lô thử (lô 3 và 4): uống chất $\mathrm{CT} 1$ ở liều lần lượt là 25 và 50 $\mathrm{mg} / \mathrm{kg}$ cân nặng/ngày.

Chuột được uống dung môi hoặc thuốc thuốc nghiên cứu hàng ngày vào một giờ nhất định, trong 7 ngày trước khi làm thực nghiệm. Thuốc đối chiếu chỉ dùng vào ngày làm thực nghiệm. Ngày thứ 7 , đo thể tích bàn chân sau phải chuột sau khi uống thuốc. Ngay sau đó tiêm dung dịch carrageenan $1 \%$ trong nước muối sinh lý $(0,05 \mathrm{ml} /$ chuột $)$ vào dưới da gan bàn chân sau phải của chuột để gây viêm. Đo thể tích bàn chân sau phải của chuột vào thời điểm 3 giờ và 5 giờ sau khi tiêm carrageenan. Mức độ phù bàn chân sau phải chuột được tính theo công thức:

$$
\Delta \mathrm{V}(\%)=\frac{\mathrm{Vt}-\mathrm{Vo}}{\mathrm{Vo}} \times 100
$$

Trong đó $\Delta \mathrm{V}$ là mức độ phù chân chuột tại thời điểm $\mathrm{t}$ giờ sau khi gây viêm; Vo là thể tích chân chuột trước khi gây viêm; Vt là thể tích chân chuột tại thời điểm $\mathrm{t}$ giờ sau khi gây viêm.

Tác dụng ức chế phù (\%) của các lô thư so với lô chưng được tính theo công thức:

$$
\mathrm{I}(\%)=\frac{\Delta \mathrm{Vc}-\Delta \mathrm{Vt}}{\Delta \mathrm{Vc}} \times 100
$$

Trong đó $\mathrm{I}(\%)$ là phần trăm ức chế phù của lô thử so với lô chứng; $\Delta \mathrm{Vc}$ là mức độ phù chân chuột trung bình ở lô chứng; $\Delta \mathrm{Vt}$ là mức độ phù chân chuột trung bình ở lô thử. 


\section{6. Đánh giá tác dụng chống viêm mạn}

Tác dụng chống viêm mạn được thử theo mô hình gây u hạt thực nghiệm trên chuột cống trắng $[10,12]$. Chuột được chia ngẫu nhiên thành 5 lô, mỗi lô 10-12 con, gồm có: Lô chứng (lô 1): uống dung môi; Lô đối chiếu (lô 2): uống thuốc đối chiếu (prednisolon); Lô thử (lô 3-5): uống thuốc nghiên cứu ở các liều khác nhau.

Các chuột được gây mê, cạo lông ở lưng và sát trùng bằng ethanol $70 \%$. Rạch và đặt ở dưới da một viên gạc bông có tẩm carrageenan vào cả hai bên xương bả vai. Chuột được uống dung môi hoặc thuốc thuốc nghiên cứu hàng ngày vào một giờ nhất định, trong vòng 7 ngày trước khi làm thực nghiệm. Ngày thứ 8 , giết chuột, bóc tách u hạt và cân. Kết quả được tính dựa trên trọng lượng khô thực của $\mathrm{u}$ hạt thực nghiệm, so sánh giá trị trọng lượng khô thực $\mathrm{u}$ hạt trung bình của lô dùng thuốc so với lô chứng và tỷ lệ \% ức chế u hạt của lô thử so với lô chứng bệnh lý.

\subsection{Tính toán kết quả}

Các số liệu thực nghiệm được xử lý thống kê theo phương pháp thống kê sinh học, sử dụng công cụ Data analysis của Microsoft Excel.

\section{Kết quả}

\section{1. Độc tính cấp của chất CT-1}

Độc tính cấp của chất CT-1 được thử trên chuột nhắt trắng, trọng lượng $18-20 \mathrm{~g}$, cả đực cả cái. Kết quả thử được trình bày ở Bảng 3.9.

Khi cho chuột uống liều đến $4,0 \mathrm{~g}$ bột $\mathbf{C T}$ $\mathbf{1} / \mathrm{kg}$ thể trọng chuột, tất cả các chuột đều khỏe mạnh, hoạt động, ăn uống, bài tiết bình thường, không có chuột chết. Khi cho chuột uống tăng liều lên đến 5,$0 ; 6,25 ; 7,80 ; 9,75 ; 12,2 \mathrm{~g}$ bột/ $\mathrm{kg}$ thể trọng thì đa số các chuột có biểu hiện phân lỏng, một số chuột bắt đầu có biểu hiện co giật sau 24 giờ, 4 chân cứng đờ, có những chuột qua được cơn co giật, một số chuột chết rải rác sau $1,2,3$ ngày uống thuốc. Ở liều càng cao thì chuột chết càng nhanh. Những chuột còn sống sót vẫn hoạt động, bài tiết bình thường, lúc đầu ăn uống ít hơn, sau đó thì bình thường. Kết quả được trình bày ở bảng 1 .

Bảng 1. Số liệu thử độc tính cấp của chất CT1

\begin{tabular}{lcccccc}
\hline Lô chuột & Liều uống $(\mathrm{g} / \mathrm{kg})$ & $\mathrm{n}$ & Số chuột chết trong lô & $\mathrm{d}$ & $\mathrm{z}$ & $\mathrm{d} \times \mathrm{z}$ \\
\hline 1 & 3,20 & 10 & 0 & & & \\
2 & 4,00 & 10 & 0 & & & \\
3 & 5,00 & 10 & 2 & 1,00 & 1,0 & 1,0 \\
4 & 6,25 & 10 & 6 & 1,25 & 4,0 & 5,0 \\
5 & 7,80 & 10 & 7 & 1,55 & 6,5 & 10,075 \\
6 & 9,75 & 10 & 8 & 1,95 & 7,5 & 14,625 \\
7 & 12,20 & 10 & 10 & 2,45 & 9,0 & 22,05 \\
$\sum(\mathrm{d} \times \mathrm{z})$ & & & & & & 52,75 \\
\hline
\end{tabular}

Theo công thức tính được $\mathrm{LD}_{50}=6,925 \pm$ $0,537 \mathrm{~g}$ bột $/ \mathrm{kg}$ thể trọng chuột ở $\mathrm{P}=0,05$. Mặc dù chất $\mathrm{CT}-1$ có độc khi thử trên chuột nhắt trắng, nhưng việc không thấy có chuột chết ở liều thử $4 \mathrm{~g} / \mathrm{kg}$ thể trọng và liều $\mathrm{LD}_{50}$ trong khoảng $(5,872$ - 7,978) $\mathrm{g} / \mathrm{kg}$ thể trọng chuột cho thấy mức độ gây độc của CT-1 rất thấp. Các kết quả chứng tỏ độ an toàn của $\mathrm{CT}-1$ khá cao và có thể thử tác dụng sinh học trên chuột nhắt trắng ở các liều thử thông thường $(0-1000$ $\mathrm{mg} / \mathrm{kg}$ thể trọng).
Trên cơ sở liều $\mathrm{LD}_{50}$ và các kết quả thử tác dụng in vitro, chúng tôi thử tác dụng chống viêm cấp và mãn của chất $C T-1$ trên chuột cống trắng ở các mức liều $25 \mathrm{mg} / \mathrm{kg} / \mathrm{ngày}$ và 50 $\mathrm{mg} / \mathrm{kg} /$ ngày.

\subsection{Tác dụng chống viêm cấp}

Tác dụng chống viêm cấp của chất CT-1 được thử theo phương pháp gây phù bằng carrageenin trên chuột cống trắng. Kết quả thử 
tác dụng được trình bày trong Bảng 2 dưới đây cho thây chuột uống chất CT-1 với liều 25 $\mathrm{mg} / \mathrm{kg} /$ ngày không đáp ứng với quá trình viêm, không giảm viêm sau khi gây phù 3 đến 5 giờ. Tuy nhiên, ở liều cao hơn $50 \mathrm{mg} / \mathrm{kg} / \mathrm{ngày}, \mathrm{CT} 1$ có tác dụng chống viêm cấp, với mức độ giảm lần lượt là 16,39 và $24,73 \%(\mathrm{P}<0,05)$. Kết quả này khẳng định chất $\mathrm{CT}-1$ có tác dụng ức chế viêm cấp khi thử trên chuột cống gây phù bằng carrageenin ở liều uống $50 \mathrm{mg} / \mathrm{kg} / \mathrm{ngày}$.

Bảng 2. Tác dụng chống viêm cấp của chất CT-1

\begin{tabular}{lccccc}
\hline \multirow{2}{*}{ Lô thí nghiệm } & Số chuột $(\mathrm{n})$ & \multicolumn{2}{c}{ Sau 3 giờ gây phù } & \multicolumn{2}{c}{ Sau 5 giờ gây phù } \\
\cline { 3 - 6 } & 12 & Độ phù $(\%)$ & $\begin{array}{c}\text { \% giảm so } \\
\text { với chứng }\end{array}$ & Độ phù $(\%)$ & $\begin{array}{c}\text { \% giảm so } \\
\text { với chứng }\end{array}$ \\
\hline $\begin{array}{l}\text { Chứng bệnh lý } \\
\text { Lô uống CT1 }\end{array}$ & 12 & $52,06 \pm 5,80$ & & $52,88 \pm 7,26$ & - \\
$\begin{array}{l}\text { (25mg/kg/ngày) } \\
\text { Lô uông CT1 } \\
\text { (50mg/kg/ngày) }\end{array}$ & 10 & $43,76 \pm 5,04$ & - & $52,91 \pm 5,29$ & 24,73 \\
$\begin{array}{l}\text { Lô uống } \\
\text { Indomethacin } \\
(20 \mathrm{mg} / \mathrm{kg} / \text { ngày) }\end{array}$ & 9 & $15,15 \pm 0,90^{*}$ & 70,89 & $4,38 \pm 1,25^{*}$ & 91,71 \\
\hline
\end{tabular}

* $\mathrm{P}<0,05$ và ** $\mathrm{P}<0,01$ so với lô chứng bệnh lý.

\subsection{Tác dụng chống viêm mãn}

Kết quả thử tác dụng chống viêm mạn được trình bày ở Bảng 3.3 cho thấy chất CT-1 ở liều thử 25 và $50 \mathrm{mg} / \mathrm{kg} /$ ngày cho tác dụng chống viêm mạn với mức độ ức chế sự tạo thành u hạt lần lượt là $24,76 \% \quad(\mathrm{p}<0,05)$ và $23,25 \%$ $(\mathrm{p}<0,01)$ và đều có ý nghĩa thống kê. Có thể thấy tác dụng ức chế ổ viêm không phụ thuộc liều dùng của $\mathrm{CT}-1$ trên chuột cống trắng ở 2 liều thí nghiệm.

Bảng 3. Kết quả thử tác dụng chống viêm mạn của CT-1

\begin{tabular}{lccc}
\hline Lô thử & $\begin{array}{c}\text { Số chuột } \\
\text { (n) }\end{array}$ & $\begin{array}{c}\text { Trọng lượng trung } \\
\text { bình ồ viêm (mg) }\end{array}$ & $\begin{array}{c}\text { \% giảm so với } \\
\text { lô chứng }\end{array}$ \\
\hline $\begin{array}{l}\text { Lô chứng bệnh lý (uống } \\
\text { nước muối sinh lý) }\end{array}$ & 10 & $521,1 \pm 32,4$ & \\
$\begin{array}{l}\text { Lô uống CT-1 } \\
\text { (25mg/kg/ngày) }\end{array}$ & 9 & $392,5 \pm 46,3$ & $24,67^{*}$ \\
$\begin{array}{l}\text { Lô uông CT-1 } \\
\text { (50 mg/kg/ngày) }\end{array}$ & 10 & $399,9 \pm 20,7$ & $23,25^{* *}$ \\
$\begin{array}{l}\text { Lô uông Prednisolon } \\
\text { (5mg/kg/ngày) }\end{array}$ & 10 & $293,3 \pm 32,5$ & $43,71^{* *}$ \\
\hline
\end{tabular}

* $\mathrm{P}<0,05$ và ** $\mathrm{P}<0,01$ so với lô chứng bệnh lý

\section{Bàn luận}

Đến nay, chất CT-1 mới chỉ được tìm thấy trong loài C. tonkinensis, chưa tìm thấy ở bất kì loài sinh vật nào khác, và chất này cũng là thành phần chính của dược liệu khổ sâm cho lá nên có thể coi CT-1 là chất đặc trưng cho loài C. tonkinensis [5]. Trước đây, tác dụng chống viêm của chất $\mathrm{CT}$-1 đã được khẳng định thông qua các nghiên cứu bằng mô hình thử in vitro, tuy nhiên chưa được khẳng định bằng nghiên cứu thực nghiệm. Trong công trình này, chúng tôi tiến hành đánh giá tác dụng chống viêm của chất CT-1 bằng một số mô hình thực nghiệm để định hướng cho việc tiếp tục nghiên cứu hoạt chất này làm thuốc chữa bệnh. Trước tiên chất 
CT-1 được đánh giá độc tính cấp trên chuột nhắt trắng để xem xét mức độ gây độc và liều thử trong các thí nghiệm tiếp theo. Kết quả cho biết $\mathrm{LD}_{50}$ của chất $\mathrm{CT}-1$ theo đường uống là $6,925(5,872-7,978) \mathrm{g}$ bột/kg thể trọng chuột (ở mức $\mathrm{p}=0,05$ ). Như vậy, có thể thử các tác dụng dược lý của $\mathrm{CT} 1$ với mức liều $<1$ $\mathrm{g} / \mathrm{kg} /$ ngày đối với chuột nhắt trắng và ở mức $<100 \mathrm{mg} / \mathrm{kg} / \mathrm{ngày}$ đối với chuột cống trắng là an toàn và kết quả có thể tin cậy được [9].

Thử tác dụng chống viêm cấp của CT-1 theo mô hình gây phù chân chuột cống trắng bằng carrageenan, một mô hình kinh điển để đánh giá tác dụng chống viêm của một hoạt chất hay một dược liệu. Kết quả cho thấy CT-1 ở liều $50 \mathrm{mg} / \mathrm{kg}$ thể hiện tác dụng chống viêm cấp tại 3 và 5 giờ sau khi gây viêm và theo quan sát thì sau 24 giờ tác dụng chống viêm vẫn còn. Tiếp theo, tác dụng chống viêm mạn của chất CT1 được thử theo mô hình gây $u$ hạt bằng amian trên chuột cống trắng. Kết quả cho thấy chất CT-1 ở cả hai mức liều $50 \mathrm{mg} / \mathrm{kg} / \mathrm{ngày}$ và $25 \mathrm{mg} / \mathrm{kg} / \mathrm{ngày}$ đều có tác dụng làm giảm khối lượng $\mathrm{u}$ hạt trên mô hình này và đều có ý nghĩa thống kê.

Các kết quả thử đã khẳng định rằng chất $\mathrm{CT}-1$ có tác dụng chống viêm cấp và mãn trên thực nghiệm, tuy tác dụng còn kém so với các chất đối chiếu dương là indomethacin và prednisolon (xem Bảng 2 và 3 ). Trong y học dân gian, khổ sâm được dùng để chữa bệnh viêm loét dạ dày tá tràng, các triệu chứng ngứa, ghẻ lở, đỏ ngoài da nên có thể chúng có liên quan đến tác dụng chống viêm. Và như vậy có thể xem xét rằng chất $\mathrm{CT}-1$, một diterpenoid chính trong lá khổ sâm, là hoạt chất của dược liệu này.

Tuy cơ chế của tác dụng chống viêm không được tìm hiểu trong đề tài này, nhưng các nghiên cứu trước đây đã phần nào cho biết về cơ chế chống viêm ở mức độ phân tử của chất CT-1. Giang và cộng sự đã chứng minh chất CT-1 ức chể NF-kappaB, một protein tham gia vào quá trình viêm, và ức chế mạnh sự tạo thành nitric oxide $(\mathrm{NO})$, do đó nó có tác dụng chống viêm [6]. Sau đó, Kou và cộng sự cũng đã khẳng định lại tác dụng chống viêm ở mô hình ức chế sự tạo thành NO thông qua việc ức chế enzyme NOS và ức chế sự hình thành gốc $\mathrm{O}_{2}^{-*}$ [7]. Ngay gần đây, nhóm tác giả này lại chứng minh rằng các chất này có tác dụng ức chế enzyme xanthin oxidase [8], là một enzym quan trọng trong quá trình chuyển hóa thành acid uric và tạo thành bệnh gút. Kết quả của công trình này góp phần chứng minh tác dụng chống viêm của hợp chất $\mathrm{CT} 1$ và cho việc định hướng sử dụng cây thuốc khổ sâm cho lá trong $\mathrm{y}$ học cổ truyền và cả y học hiện đại.

\section{Kết luận}

Hoạt chất chính của lá khổ sâm CT-1 ở liều uống $50 \mathrm{mg} / \mathrm{kg}$ thể trọng có tác dụng ức chế viêm cấp trên mô hình gây phù bàn chân chuột cống bằng carragenin và có tác dụng chống viêm mạn trên mô hình gây u hạt thực nghiệm bằng amian ở chuột cống trắng với liều uống 25 $\mathrm{mg}$ và $50 \mathrm{mg} / \mathrm{kg}$ thể trọng. Kết quả cho thấy chất $\mathrm{CT}-1$ có tác dụng chống viêm cấp và mạn và có thể xem xét rằng chất $\mathrm{CT}-1$, một diterpenoid chính trong lá khổ sâm, là hoạt chất của dược liệu này.

\section{Lời cảm ơn}

Nhóm tác giả trân trọng cám ơn Quỹ phát triển Khoa học và Công nghệ Quốc gia (Nafosted) đã tài trợ cho nghiên cứu này thông qua đề tài mã số 106-YS.05-2014.32.

\section{Tài liệu tham khảo}

[1] Đỗ Huy Bích và cộng sự (2004), Cây thuốc và động vật làm thuốc ở Việt Nam, NXB Khoa học và Kỹ thuật, Hà Nội, tập II, tr. 87-89.

[2] Bộ Y tế, Dược điển Việt Nam IV, NXB Y học, 2009.

[3] Võ Văn Chi (1997), Từ điển cây thuốc Việt Nam, NXB Trẻ, TP Hồ Chí Minh, tr. 622-623.

[4] Đỗ Tất Lợi (2001), Các cây thuốc và vị thuốc Việt Nam, NXB Y học, tr. 826. 
[5] Phương Thiện Thương và cs (2011), Tổng quan nghiên cứu về thành phần hóa học và tác dụng sinh học của cây khổ sâm cho lá, Tạp chí Dược liệu $16(1+2), 9-19$.

[6] Giang P.M. et al. (2003), ent-Kaurane diterpenoids from Croton tonkinensis inhibit LPS-induced NF$\kappa \mathrm{B}$ activation and NO production, Journal of Natural Products 66, 1217-1220.

[7] Kuo P.C. et al. (2007), Crotonkinins A and B and related diterpenoids from Croton tonkinensis as anti-inflammatory and antitumor agents, Journal of Natural Products 70, 1906-1909.

[8] Kou P.C. et al. (2013), Anti-inflammatory diterpenoids from Croton tonkinensis. Journal of Natural Products 76, 230-236.
[9] Trần Thu Hiền và công sự (2016), Nghiên cứu chiết xuất, phân lập hợp chất diterpenoid chính từ cây khố sâm cho lá (Croton tonkinensis Gagnep.), Tạp chí Dược học 56 (483), 60-62.

[10] Viện Dược liệu (2006), Phương pháp nghiên cứu tác dụng dược lý của thuốc từ thảo dược, NXB Khoa học và Kỹ thuật.

[11] Winter, C.A., Risley, E.A., Nuss, G.W. (1962), Carrageenan-induced edema in hind paw of the rat as an assay for anti-inflammatory drugs, Proc. Soc. Exp. Biol. 11, 544-574.

[12] Wang J. et al. (2011), Topical anti-inflammatory and analgesic activity of kirenol isolated from Siegesbeckia orientalis, J. Ethnopharmacol. 2011, 137, 1089-1094.

\title{
Effects on Acute and Subchronic Inflammation of ent-7 $\beta$ - Hydroxy-15-oxokaur-16-en-18-yl acetate Isolated from the Medicinal Plant Croton tonkinensis Gagnep
}

\author{
Nguyen Van Thoan ${ }^{1}$, Tran Thi Thu Hien ${ }^{2}$, \\ Nguyen Duy Thuan ${ }^{2}$, Phuong Thien Thuong ${ }^{3}$ \\ ${ }^{1}$ Research Institute of Oriental Medicine and Pharmacy, National Pharmaceutical Joint-Stock Company, \\ 119 Nguyen Ngoc Nai, Thanh Xuan, Hanoi \\ ${ }^{2}$ Vietnam University of Traditional Medicine, 2 Tran Phu, Ha Dong, Hanoi \\ ${ }^{3}$ National Institute of Medicinal Materials, 3 B Quang Trung, Hoan Kiem, Hanoi
}

\begin{abstract}
In this study, the effects of compound ent-7 $\beta$-hydroxy-15-oxokaur-16-en-18-yl acetate (CT1) from the plant Croton tonkinensis Gagnep. on acute and chronic inflammations were evaluated by in vivo models. It was found that compound CT1 reduced $24.73 \%(\mathrm{P}<0.05)$ of acute inflammation in a carrageenan-induced paw edema assays at oral dose $50 \mathrm{mg} / \mathrm{kg} /$ day after 5 hours injecting carrageenan. At $25 \mathrm{mg} / \mathrm{kg} / \mathrm{day}$ oral administrated, this compound also exhibited chronic inflammation with an inhibitory effect of $24.67 \%(\mathrm{P}<0.05)$ on a cotton pellet-induced granuloma formation model. This study suggests that the compound CT1 possesses the anti-inflammatory activity and could be the active principle of the plant Croton tonkinensis in ethnomedicinal uses.
\end{abstract}

Keywords: Croton tonkinensis, ent-7 $\beta$-hydroxy-15-oxokaur-16-en-18-yl acetate, antiinflammatory activity. 